\title{
Tasks and Strategies of In-house Lobbyists in American Colleges and Universities
}

Received (in revised form): November 17, 2004

\section{Scott Ellis Ferrin}

Professor Ferrin received his JD and BA from Brigham Young University, his M.Ed. and Ed.D. from Harvard, and is currently an Associate Professor of Educational Leadership and Foundations and Adjunct Professor of Law at Brigham Young University. He has been the Executive Assistant to three college presidents.

\begin{abstract}
How do in-house lobbyists for American colleges and universities compare with other types of lobbyists in their roles, tasks, and strategies? To answer this question 105 in-house lobbyists were surveyed using an instrument that reiterated key questions asked in earlier researchers' studies on private or special interest lobbyists, such as the gun lobby, and public interest lobbyists such as consumer, or environmental groups.

This replication of research with other types of lobbyists made it possible to compare and contrast the tasks and strategies of in-house lobbyists with those of other types of lobbyists. Also 20 indepth on-site interviews of in-house lobbyists were conducted at universities across the country to learn more regarding their roles, tasks, and strategies; and interviews were conducted with ten
\end{abstract}

\footnotetext{
Author's Contact Address:

Scott Ellis Ferrin, J.D., Ed.D.

Associate Professor of Educational Leadership \& Foundations

Brigham Young University

306-H MCKB

Provo, UT 84602

USA

Phone: + 18014224804

Email: ferrin@byu.edu
}

presidents from among those 20

universities to provide another viewpoint on the roles, tasks, and strategies of inhouse lobbyists in universities.

\section{Keywords:}

politics, lobbying, higher education, lobbyist, tactics

\section{Introduction}

The word "lobby," applied to activities meant to influence government, appeared in print in the United States as early as 1808. ${ }^{1}$ Today most medium to large universities, and many smaller colleges, recognize a need to influence local and national government through lobbying. The current proliferation of lobbying offices on such campuses is the result. (This proliferation of lobbyists and lobbying programs is noted by all these interviewed in this research, including the interview estimates of Shelley Steinbach, Director of Government Relations, American Council on Education, and John Vaughan, Director of Federal Relations, American Association of Universities.) In-house lobbyists for American colleges and universities are unique and powerful professionals who differ from "outside" contract or firm 
lobbyists, and from lobbyists for other types of organizations and interest groups, in several ways. They are paid a salary rather than a contracted fee; have only one client, their college or university; usually have some input in defining their institutions' goals and their own tasks; and they have unique clients who enjoy an unusual amount of goodwill in American society. Throughout this article the generic term "in-house lobbyist" will often be used to indicate the subjects of this research-in-house lobbyists for American colleges and universities. The few references in this article to in-house lobbyists representing other types of organizations will be made clear in context.

Do in-house lobbyists for colleges and universities differ from other types of lobbyists in their roles, tasks, and strategies? In-house lobbyists studied in this research all claimed that their role was unique, and that they perform tasks and meet objectives differently from other types of lobbyists. In fact, the vast majority of the in-house lobbyists for colleges and universities studied felt that their roles were so unique that they would never consider acting as a lobbyist for any other type of client. One noted:

Lobbying tactics in lobbying for [corporation name removed] would be different. I think the tactics of lobbyists have to relate to the kinds of interests they're representing and I wouldn't be into lobbying for-well, it would be difficult to see myself lobbying in other than the interests of the university in the field of higher education, where I think the institutional purposes and goals ... are highly compatible with my own value system. (Interview of in-house lobbyist B. Note that in this research in-house lobbyists were guaranteed confidentiality. To preserve this confidentiality in-house lobbyists were assigned a letter or letters "In-house Lobbyist A," and presidents were assigned a number, "President \#1." Because the professional world of inhouse lobbyists at American colleges and universities is very small, no further descriptions are given, so that in-house lobbyists or presidents will not be able to identify each other.)

When investigating a subject: " $[\mathrm{O}]$ ne makes gradual sense and does it in large part by contrasting, comparing, replicating, cataloguing, and classifying the object of one's study."2 This research contrasted, compared, and replicated earlier research to help define and illuminate the tasks and roles of in-house lobbyists in colleges and universities by comparing their responses and roles to similar research with other types of lobbyists. One hundred and five in-house lobbyists were surveyed utilizing a lengthy and open-ended survey instrument that reiterated key questions asked in earlier studies on private interest or special interest lobbyists, such as the gun lobby, ${ }^{3}$ and public interest lobbyists such as consumer, or environmental groups. ${ }^{4}$

As further background to the comparative analysis of the survey results, 20 in-house lobbyists at institutions across the United States were interviewed at their campuses, following which ten presidents were interviewed telephonically at ten of the same institutions. All interviews were taped, transcribed, and coded.

\section{Comparative Lobbying Tactics and Strategies}

Milbrath and Zeigler and Baer compiled data on the tactics and strategies employed by "private interest" lobbyists, also known as industry lobbyists, or 
special interest lobbyists. ${ }^{5}$ Berry later did similar research with "public interest" lobbyists, at a time when public interest lobbyists and lobbying groups were a relatively new phenomenon. ${ }^{6}$ Similarly, the proliferation of in-house lobbyists and lobbying offices at colleges and universities may be a relatively new phenomenon. Since, arguably, colleges and universities are still perceived as operating in a broad sense in the public interest, public interest lobbyists and in-house lobbyists at colleges and universities might be expected to share some common traits since they work for groups motivated more by ideological or values-based issues than do other lobbyists.

\section{Open denunciation of opponents}

Berry found that his public interest lobbying group responded similarly to private interest lobbyists when rating the effectiveness of almost all tactics or strategies. For example, both types of lobbyists chose face-to-face meetings with legislators as their most effective lobbying strategy. However, Berry claims that his public interest lobbyists differed radically from private interest lobbyists in one respect-their use of the tactic of "open denunciation" of an opponent. Private interest lobbyists rarely, if ever, used the tactic of "open denunciation" in their lobbying efforts. In fact, Milbrath did not even include this tactic in any charts, since he found it was not used by his private interest subjects.

In contrast to private interest lobbyists, Berry claims that his public interest lobbyists regularly employ the tactic of "open denunciation" against legislators unsympathetic to their cause, and even against their "friends" from time to time. According to Berry, public interest lobbyists view "open denunciation" as a sanction that will make legislators think in the future of the high cost of opposing their objectives.

When asked to rank the effectiveness of "open denunciation" on a scale of $0-4$, with 4 being the highest, in-house lobbyists for universities ranked it a distant last among all lobbying tactics, with an average score of 0.39 . This compares to their average rating of 3.62 for "personal communication with legislators," and 3.59 for "monitor legislation" (see Figure 1). Clearly, inhouse lobbyists are not completely like public interest lobbyists in all their attributes since they do not value this tactic.

In-house lobbyists at colleges and universities benefit from long-term continuing friendships and associations with politicians and policy makers. Many of the objectives they pursue, such as a tuition hike, will not resonate with large groups of the public. This may explain why they tend to eschew "open denunciation" as a lobbying tactic, and seem similar to private interest lobbyists in this respect. In-house lobbyists for colleges and universities are apparently engaged in a "a process of trying to activate sympathetic partisans rather than . .. persuading the uninformed. ..." 8 They seem to be followers of the conventional wisdom, as best stated by Bauer et al. that it is most strategic to lobby their "friends" in government and leave their "enemies" alone.

\section{Other Comparative Rankings of Lobbying Tactics by In-house Lobbyists, Public Interest Lobbyists, and Milbrath's Private Interest Lobbyists}

The following will focus on several other significant tactics as rated by each group. 
Berry arranged his subjects' answers by percentage who rated each tactic from "very effective," to "not effective" (see Figure 1). Milbrath's subjects rated lobbying tactics on a Likert scale of 1-10 and in-house lobbyists in this research ranked the same tactics on a Likert scale of $0-4$, or a five-point scale. Because of the differences in scales, and differences in presenting these lobbying tactics to subjects, no attempt has been made to argue that these comparisons between different types of lobbyists are statistically valid. They are intended to provide an indication of broad differences and similarities between in-house lobbyists for colleges and universities and other types of lobbyists.

This list of tactics has been developed over time by Milbrath, Berry, and this researcher, to include only the most effective tactics used by lobbyists. Since this is a rating among those tactics already expected to be effective, differences in ranking are comparatively subtle. Figure 1 shows the rankings of each group.

\section{Personal presentation}

All three types of lobbyists agreed that the most effective tactic or method of lobbying was personal presentation of argument to governmental officials. Milbrath's private interest lobbyists rated the tactic 8.43 on a scale of 1-10. Berry's public interest lobbyists rated this tactic the highest of the available choices, 53 percent of them rating personal presentation "very effective." In-house lobbyists at colleges and universities also rated this tactic the highest of all choices, rating it 3.62 on a scale of $0-4$. Although Zeigler and Baer's private interest lobbyists are not included graphically, since they did not discuss each tactic studied in this research, they too ranked direct personal contact as the most effective lobbying technique. They noted: "There is practically no variation in lobbyists' evaluation of this technique... Lobbyists everywhere . . consider personal presentation of arguments to be more effective than either the presentation of research results or testimony at hearings." "They also noted

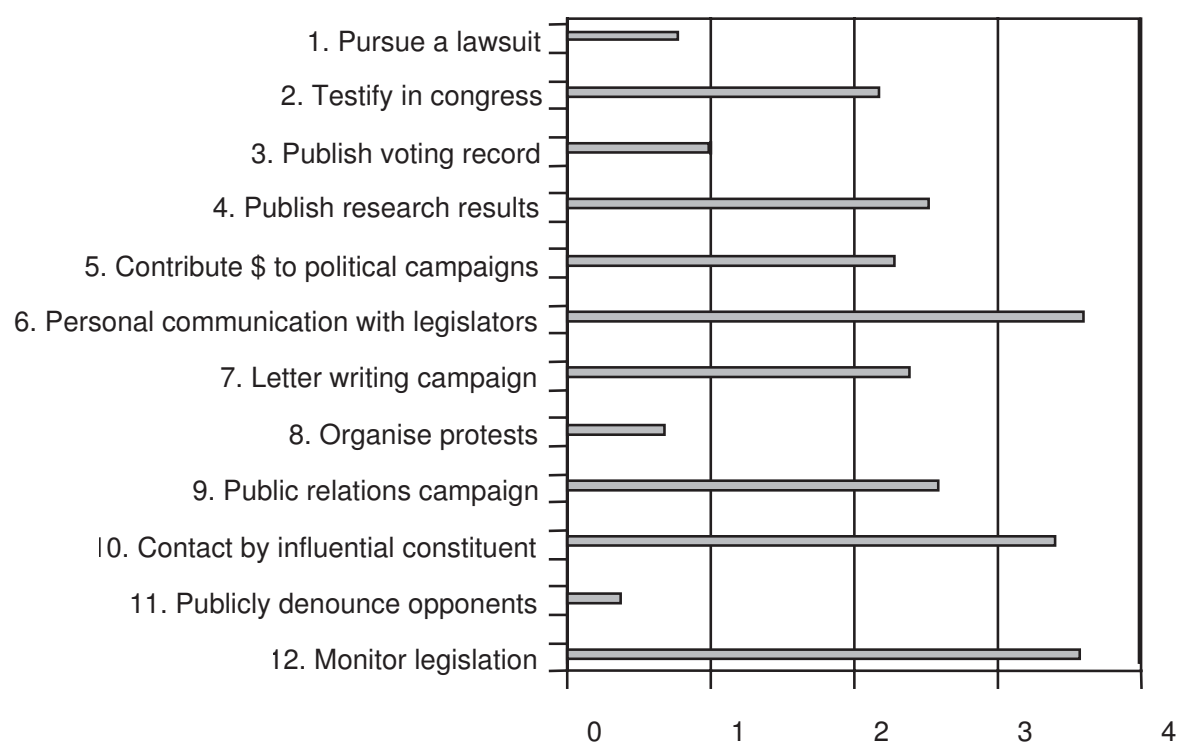

Figure 1: In-house lobbyists: Effectiveness of lobbying tactics and strategies (4-point scale) 
that the legislators they studied as a part of their research ranked this tactic as the most effective lobbying technique lobbyists used on them.

\section{Contact by an influential constituent (or alumni)}

In-house lobbyists ranked having an influential constituent contact important legislators or decision makers a high second, scoring it at 3.41 on a scale of $0-4$. It was ranked a distant third by Berry's public interest lobbyists, and fourth by Milbrath's Washington private interest lobbyists (see Figure 1). Milbrath asserts that members of large groups with large memberships rate constituent contact higher than other lobbyist representatives for small private interests. ${ }^{11}$ The fact that colleges and universities usually have a relatively large and committed group of alumni and friends that support their mission may explain why in-house lobbyists rank this tactic higher than do other types of lobbyists. Truman notes that a high-status group usually enjoys more access than do others. "Its petitions and claims may even in some instances appear less as demands or supplications and more as flattery of the official of whom a favor is asked." 12

Colleges and universities have access to high status constituents and alumni who can make contacts for the college or university.

In direct contrast to Berry's assertion about public interest lobbyists-that they rank contact by influential constituent or friend highly but only use the tactic infrequently-in-house lobbyists at colleges and universities also use the tactic frequently, in fact it ranked second in frequency (see Figure 1). In this respect, in-house lobbyists seem to differ markedly from public interest lobbyists. Evidently, colleges and universities have relatively large pools of "high status" individuals to draw from who can serve as influential

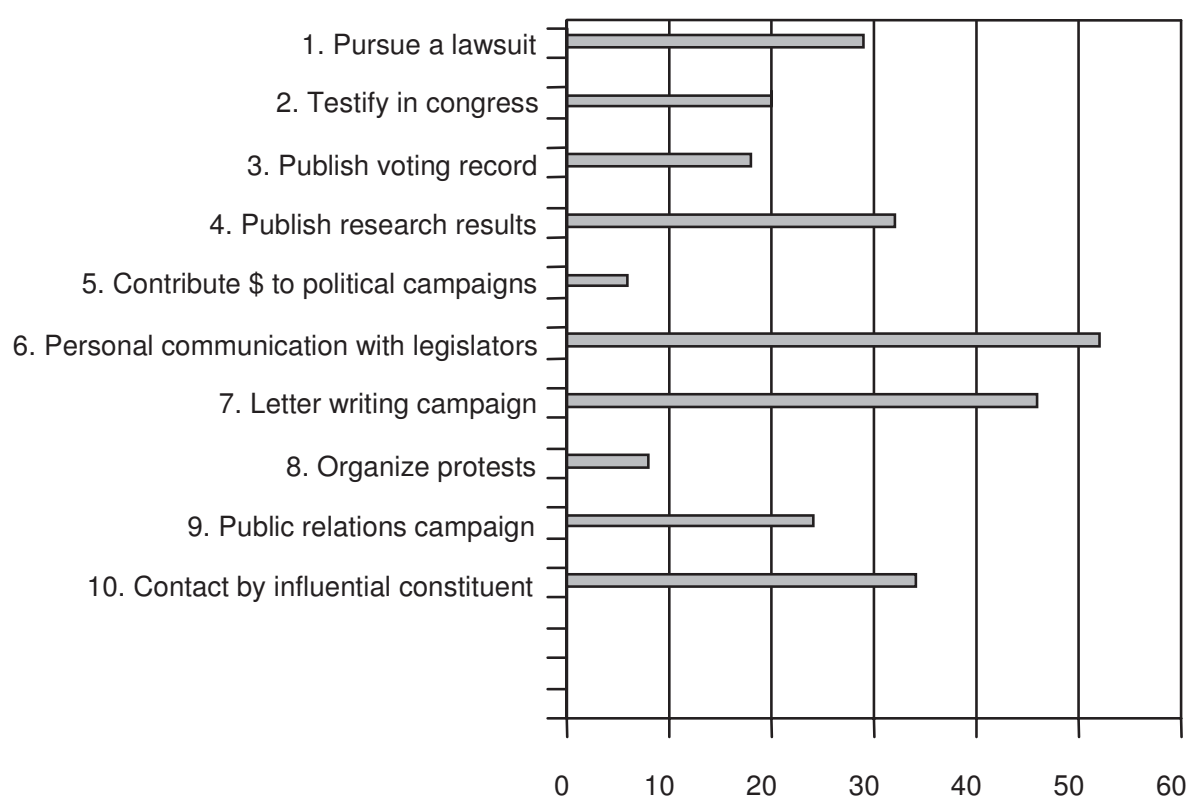

Figure 2: Berry's public interest lobbying: Tactics and strategies (Percentage ranking) 
contacts, without the danger of exhausting a few committed "organizational influentials."

\section{Organizing a public relations campaign}

In-house lobbyists ranked organizing a public relations effort third, scoring it 2.60 on a scale of $0-4$, while private interest lobbyists ranked it a relatively low fifth, and public interest lobbyists ranked it sixth (see Figure 1). Berry explains why he believes public interest lobbyists do not rank this tactic highly.

... [F]ew groups allocate more than a marginal amount for advertising, electronic media presentation, and the like. The primary reason for the low resource commitment is the sheer cost involved in public relations. It is simply too expensive for most groups to use to any significant degree. ${ }^{13}$

For a public interest lobbying group, public relations requires an expensive outreach to what is often a national constituency, or at least a broad constituency. The hope is to attract the constituency by exposing them to the organization's issues, since by definition they are meant to be of benefit to the public. Similarly, a private interest lobbyist will need expensive media support to make an effective impact in a public relations campaign. The tobacco industry must purchase advertising to inform the public about their position on legislation that threatens smokers and the tobacco industry.

After interviewing in-house lobbyists at colleges and universities, however, it becomes apparent that in-house lobbyists may define public relations campaigns differently than do public interest lobbyists and private interest lobbyists.
One in-house lobbyist interviewed in this research saw managing public relations as a part of his normal duties.

Our goal is that what the development office is doing on the fundraising side, and what the alumni office is doing on the fundraising side, what our public relations and public information strategies in terms of what kinds of news stories are we looking to generate, what we are doing in Washington, what we are saying to the state legislature, is called the Integrated Campaign. It's a strategy that links all those things together so that if I go to a Rotary Club meeting, and I hear [a university speaker], then I go to an economic development program and hear [a university speaker], and I go to the legislature and hear [a university speaker], I'm going to hear the same things. My role has been very much to keep all of the message together. (Interview of in-house lobbyist $\mathrm{O}$ )

By the nature of the goodwill and the active constituents associated with colleges and universities, organizing a public relations campaign does not need to be terribly expensive. Press releases are free, and releases about universities are often newsworthy simply because they emanate from an important local or national college or university, and because there is usually a reporter on local or state newspapers assigned permanently to the university "beat" who is willing to pick up important stories about that local college or university. This may make it more likely that press releases from inhouse lobbyists and their universities and colleges will be given wide and no-cost currency by the media.

Most colleges and universities also enjoy a motivated group of friends of the 
university who are willing to magnify the effects of any public relations campaign. This includes alumni, local area business persons whose economic welfare and development are affected by issues that affect the college, students and their families, faculty and their families, trustees, and others. These groups may be mobilized through low-cost means such as university alumni newsletters, email lists, community relations councils, student newspapers, and tightly focused mailings.

\section{Releasing research results}

A close fourth as an effective lobbying tactic (2.53 on a scale of $0-4)$ chosen by in-house lobbyists is the release of research results that support the organization's position. Berry's public interest lobbyists also chose this as their fourth ranked tactic, but surprisingly, Milbrath's private interest lobbyists chose this tactic as their second highest rated tactic, scoring it 7.4 on a scale of 1-10. Berry explains how research results are utilized by public interest lobbyists.

The first means of communications is the press release, which highlights the research or other information the group has available. Writing a good press release is somewhat of an art, where care must be placed in actually writing the story for the press. The first part of a press release should be written as if it were the lead paragraphs of a newspaper story. When the Washington Post reported in its May 7, 1973, edition that "The Center For Auto Safety said yesterday that an electrical relay in 1969 and 1970 Cadillacs constitutes a serious fire hazard," they were surely reprinting the first sentence of a Center press release. $^{14}$

While Milbrath says:

Some types of organizations utilize release of research results more than

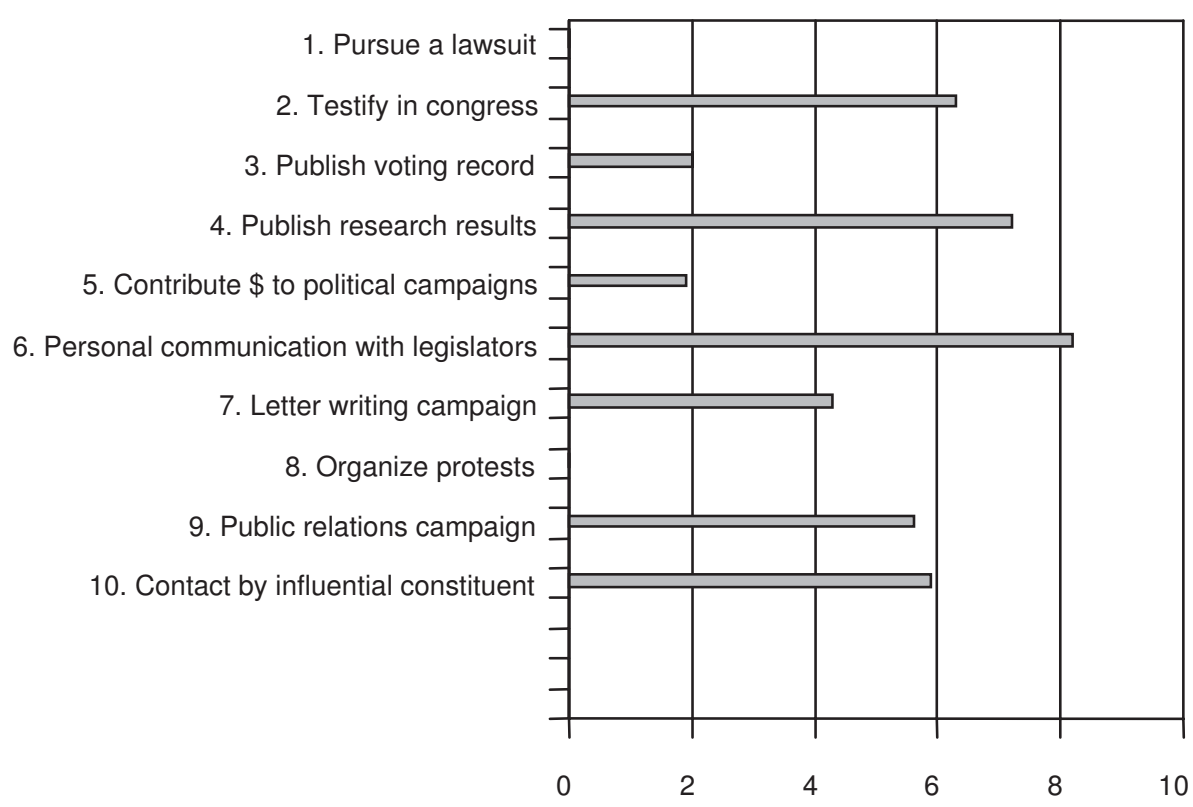

Figure 3: Milbrath's private interest lobbyists: Lobbying tactics and strategies (0-10 scale) 
others. Lobbyists for organizations with a specialized subject matter emphasize research more than others. And lobbyists for small organizations emphasize research more than those from large organizations. Large organizations are less inclined to be specialized, and they generally have greater political resources to throw into the battle. ${ }^{15}$

Of course, in-house lobbyists at colleges and universities are part of a large organization, usually with broad and general aims. Milbrath suggests that these are characteristics that make organizations less likely to emphasize research. University in-house lobbyists' relatively low ranking of this tactic seems to bear Milbrath out.

In-house lobbyists are generally from rather large organizations, that are somewhat general in their aims. As such they may down play the release of research as Milbrath noted above The above explanation seems to explain in-house lobbyists' relatively low rating of the tactic of releasing research. It does not explain why Milbrath's subjects rated the tactic as the second highest lobbying tactic.

It might have been thought that inhouse lobbyists at colleges and universities would rank releasing research results slightly higher because their institutions are so intimately involved in research. One of the most likely reasons in-house lobbyists at colleges and universities rank the release of research results so low compared with Milbrath's group is that, although colleges and universities are deeply involved in research, most faculty do not conduct research on the university itself or the issues that the university's inhouse lobbyist seeks to affect.

For the sake of brevity the other lower ranked tactics studied in this research will not be discussed fully. Of those though, it

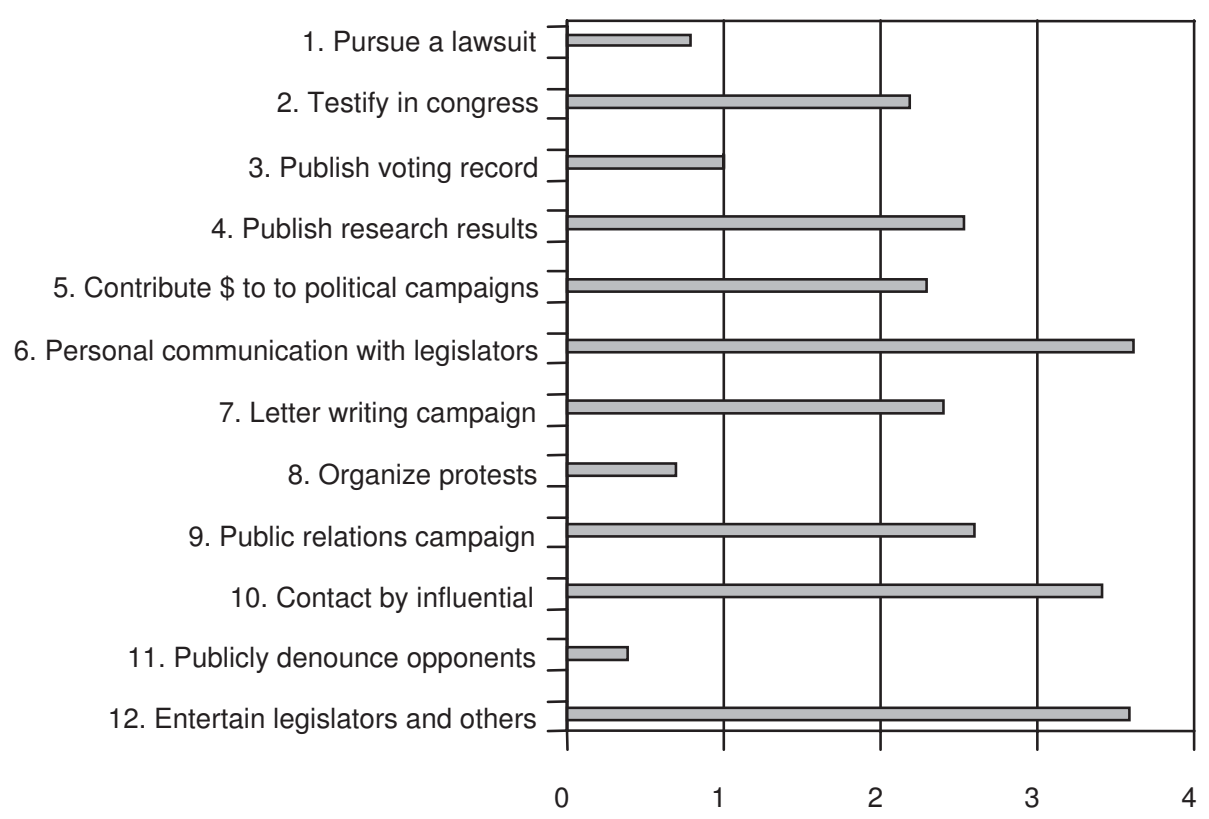

Figure 4: In-house lobbyists: Effectiveness of own lobbying techniques and strategies (0-4 scale) 


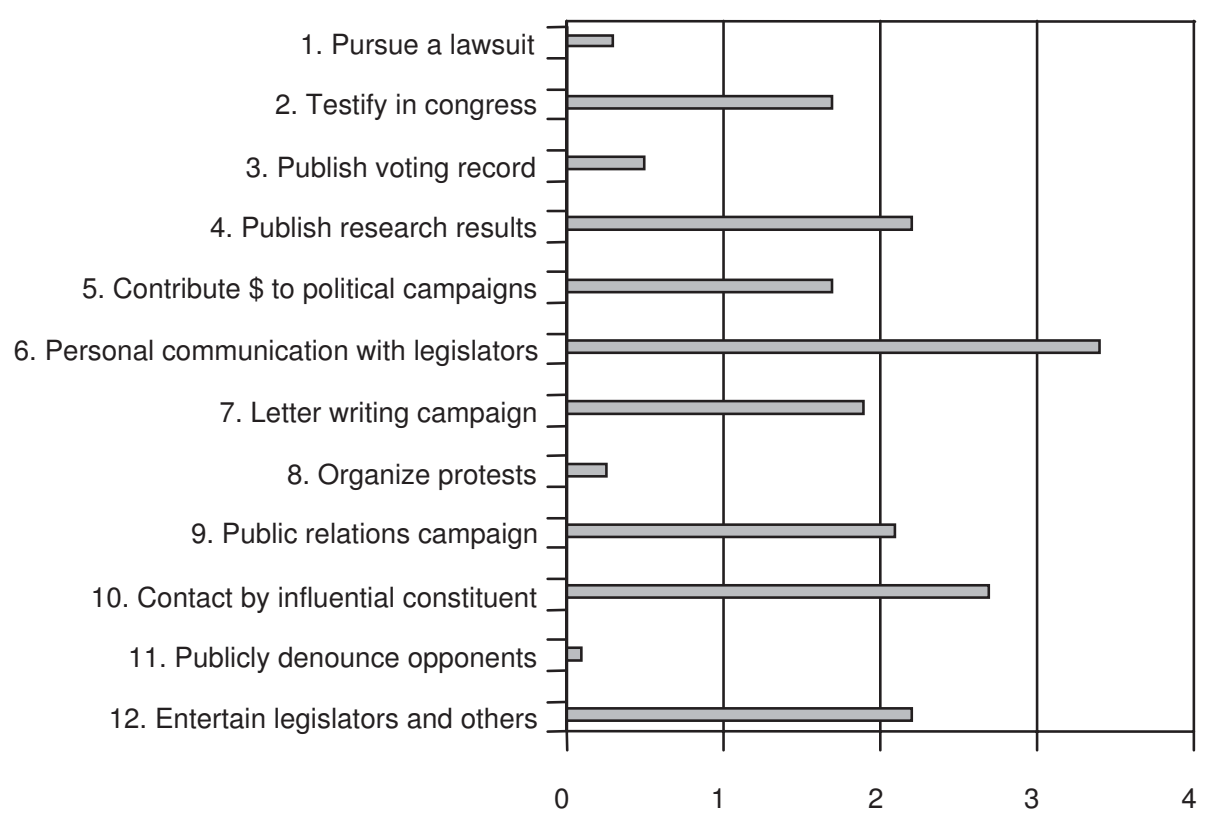

Figure 5: In-house lobbyists: Frequency of use of lobbying tactics and strategies (0-4 scale)

is interesting that the groups diverged in their rankings. In-house lobbyists rated letter writing campaigns fifth, Milbrath's group rated it sixth, but Berry's group rated this as their second most effective lobbying strategy. Berry says: "The rationale behind letter writing is very simple. Public interest representatives strongly believe that government officials are quite sensitive to the mail their offices receive and that members of Congress, in particular, really do listen to their constituents."16

In-house lobbyists for colleges may be limited in their ability to call on a constituency who can provide a large, well-orchestrated letter writing campaign that appears to be "grass-roots originated." A letter writing campaign urging Congress to give a research center to a certain state university will not appear to be a grassroots initiated issue. It will be clear that the information about the issue must have emanated from the university.

\section{Contributing money}

In-house lobbyists in colleges and universities rated contributions to political campaigns fifth, but Milbrath and Berry both rated this tactic last, or tenth (see Figure 1). This is an interesting result which should be explored more fully. Does it mean that in-house lobbyists and their colleges or universities contribute to political campaigns more than any other type of lobbyist? Do they even have the resources to make a significant impact?

In 1992, The Chronicle of Higher

Education reviewed campaign contributions given in early 1992 to the 14 members of the Senate Subcommittee on Education, Arts, and the Humanities, and to the five Democrats and the five top Republicans of the 27-member House Subcommittee on Postsecondary Education. The Chronicle's review indicates that contributions from college officials were greatly overshadowed by 
those from banks, trade schools, and public primary and secondary education. For example, William Ford, who headed the House Education and Labor Committee and the House Subcommittee on Postsecondary Education, received $\$ 6,450$ from college officials and their lobbyists from January 1991 to March 1992. However, during that same time period, trade school officials donated $\$ 10,350$. College officials donated $\$ 2,482$ to the campaign of Senator Dan Coats, a member of the Senate Subcommittee on Education, Arts, and the Humanities, but this is overshadowed by the $\$ 34,781$ contributed by bankers to his campaign, and it pales in comparison to the $\$ 1.794$ million total he received in contributions during that time period. Pat Williams of Montana received a minor sum, $\$ 4,385$, from college officials and their lobbyists, but she received a relatively healthy $\$ 19,750$ from teacher union political action committees. ${ }^{17}$ It seems clear that colleges and universities do not contribute large amounts to federal campaigns. The following in-house lobbyist rated campaign contributions as potentially very highly effective. He laments, however, that his university community is relatively unwilling to give to political campaigns. In his interview response he said:

"Contributing money to political campaigns." Give that a four (the highest rank on a $0-4$ scale). And find me a successful program where it's not a four and let me go look at it. ... Should I encourage others to give? That's a real problem I have. I've got a new Provost, for example, and I can't get him to understand that it would immensely help him to write a check for one hundred bucks. (Interview of in-house lobbyist $S$ )
Another in-house lobbyist makes a similar point. He finds it very difficult to "train" higher education administrators and others to give to political campaigns at a level similar to that normal for other groups of professionals.

Last but not least-it's true all over the country, I'm told-even university people who make $\$ 80,000$ to $\$ 100,000$ a year are very cheap when it comes to political donations. They're very naive, and it's very hard to educate them. They think $\$ 25$ bucks is a big donation and they think if they give a couple of hundred bucks during an election period that that's a lot of money. I pick one or two a year. I may throw a fundraiser for somebody, actually get 20 people to come to my house, actually raise \$5-6,000 bucks for them, and I get a couple of people who think "Well, at least he did something." But I can only do that for one or two people in an election season. (Interview of in-house lobbyist G)

Interview data from in-house lobbyists hints that the explanation for the relatively high ranking of "political campaign contributions" by in-house lobbyists at colleges and universities may be that most in-house lobbyists were ranking the effectiveness of personal contributions by administrators and faculty, while public interest lobbyists and private interest lobbyists may have been considering political contributions from their organization's funds when they ranked the tactic last. Interview data shows that in-house lobbyists generally would not even consider giving university funds for political campaign contributions.

\section{Conclusion}

In-house lobbyists at colleges and universities have a unique defining set of tactics they employ which differentiates 
them from other types of lobbyists. Compared with other types of lobbyists, in-house lobbyists rank "campaign contributions" and "organizing public relations campaigns" surprisingly high, yet "publishing research results" is ranked surprisingly low. Although explanations of the differences between types of lobbyists are debatable, in-house lobbyists have their own unique characteristics when all tactics are considered together. This tends to confirm the assertion of in-house lobbyists themselves that they act differently as a group than do other types of lobbyists. They also seem to have strong opinions on what does or does not work as tactics to advance the goals of universities and colleges. In-house lobbyists appear to be unique and potentially powerful leaders in American higher education who choose their own advancement tactics to fit the unique contours of higher education's environment.

\section{References}

1. J. Deakin (1966), The Lobbyists, Public Affairs Press, Washington, DC.
2. M. B. Miles and A. M. Huberman (1984), Qualitative Data Analysis: A Sourcebook of New Methods, Sage Publications, Newbury Park, CA, p. 37.

3. L. W. Milbrath (1963), The Washington Lobbyists, Rand McNally, Chicago; H. Zeigler and M. Baer (1969) Lobbying: Interaction and Influence in American State Legislatures, Wadsworth, Belmont, CA.

4. J. M. Berry (1977), Lobbying for the People: The Political Behavior of Public Interest Groups. Princeton University Press, Princeton, NJ.

5. Milbrath (1963), The Washington Lobbyists, op. cit.; Zeigler and Baer (1969), Lobbying, op. cit.

6. Berry (1977), Lobbying for the People, op. cit.

7. Ibid., pp. 216-23.

8. Ibid., p. 217.

9. R. A. Bauer, I. S. Pool, and A. L. Dexter (1963), American Business and Public Policy. Atherton Press, New York, p. 353.

10. Zeigler and Baer (1969), Lobbying, op. cit., pp. 174-5, emphasis added.

11. Milbrath (1963), The Washington Lobbyists, op. cit., p. 244.

12. D. B. Truman (1971), The Governmental Process, 2nd edn. Alfred A. Knopf, New York, p. 265.

13. Berry (1977), Lobbying for the People, op. cit., p. 250.

14. Ibid., p. 244.

15. Milbrath (1963), The Washington Lobbyists, op. cit., p. 228.

16. Berry (1977), Lobbying for the People, op. cit., p. 234.

17. T. J. Deloughey (1992), "Banks and trade schools increase their campaign gifts as congress reauthorizes the Higher Education Act," Chronicle of Higher Education, May 20, p. A20.

\section{Practitioner's Perspective}

Government relations professionals are vital members of the higher education community, and have been for decades. However, many of my colleagues at campuses around the country have worked in relative anonymity, at least compared with fellow advancement professionals. Ironically, though, the role of the government relations officer has never been as important as it is today. As state governments around the country slash higher education budgets and as colleges and universities face new mandates from the federal government, the role of the in-house higher education lobbyist has become vital to institutional success. However, as any good higher education professional will tell you, this is no new event; in-house lobbyists have always been crucial leaders in higher education.

Advancement is defined as the systematic integrated method of managing relationships in order to increase an educational institution's support from its key outside constituents. As Scott Ellis Ferrin illustrates in his examination of in-house higher education lobbyists, this is exactly their role. Like other lobbyists, higher education lobbyists rank personal contact with legislators as their number one tactic, 
according to Ferrin. However, they differ from other lobbyists in that they rank the use of influential alumni or constituents as their number two tactic. As the author points out, this is not surprising, as colleges and universities have more high-status alumni than do their other public sector or even private sector counterparts. A major area, however, where higher education lobbyists differ from their colleagues, is through their use of the media. Public sector lobbyists from outside higher education did not identify the use of a media as an important tactic, most likely due to the cost of mounting a PR campaign. Ferrin concludes though that campuses have a "special relationship" with the media, which oftentimes has college "beat" reporters who are assigned to cover the campus. This, along with the use of press releases and a large group of motivated friends of the university, helps make using the media both a relatively inexpensive and enormously useful tactic for in-house lobbyists. Ferrin's conclusion illustrates a fact many of us have known for years: the role of the higher education lobbyist is unique, and growing in importance.

Higher education lobbyists have long existed in a sort of no man's land, neither a compatriot of other public sector lobbyists, nor a fully accepted member of many campuses. The work of the government relations officer has long been taboo for many in higher education: necessary work, but not always readily admitted to. We are now in the midst of a powerful paradigm shift in the field of both government relations and advancement, one that recognizes that in-house lobbyists are advancement professionals in the truest sense of the word. Just like the development, alumni affairs, or communications officer, the lobbyist adeptly manages relationships from outside constituencies in order to support the institution. This unique role is so different from any other type of lobbyist that it forever gives the higher education lobbyist a valuable position in the higher education universe.

Matthew Long Government Relations Director, Council for Advancement and Support of Education 